\title{
GEOTECHNICAL AND GEOCHEMICAL STUDIES ON CARBONATES AND THEIR SUITABILITY FOR ROAD BASES AND CEMENT INDUSTRIES, ELQATAMIYA- AIN SUKHNA ROAD, EGYPT
}

\author{
Kamel, S. A. ${ }^{1}$, Ibrahim, A. M. ${ }^{1}$, and Elsayed, A. L. ${ }^{2}$ \\ 1 Al-Azhar Univ. Faculty of Science, Geology Department, Cairo, Egypt \\ 2 Arab Contractor Company - Cairo, Egypt
}

\begin{abstract}
The present study deals with geochemical, geotechnical and mineralogical studies of Lower Eocene carbonate rocks at El-Qatamiya- Ain Sukhna road and their suitability for road base and cement industries. The studied area lies between Latitudes $29^{\circ} 37^{\prime} 43^{\prime \prime}$ and $29^{\circ} 59^{\prime} 45^{\prime \prime} \mathrm{N}$. and longitudes $32^{\circ} 20^{\prime} 43^{\prime \prime}$ and $32^{\circ}$ $19^{\prime} 48^{\prime \prime} \mathrm{E}$.

Lithologic studies of Lower Eocene (Ypresian) sediments are subdivided into two Formations in the G. Galala area from base to top: Galala Fm. and Minia Fm. were recorded. Physical properties studies of Lower Eocene carbonate rocks were made (at Arab Contractor Labs) on some raw materials (Limestone, Dolomite and Clay) detected in the studied area show their validity for road base constructions.

The chemical composition major oxides were done using X-ray flourcense analysis on carbonate sections shows their suitability for cement industry. Silica modulus (S.M) factor, Alumina ratio (A.R) and Lime saturation factor (L.S.F) in Portland cement reveals that the studied carbonate sections (Galala area) raw materials are very suitable for cement industry.
\end{abstract}

Keywords: Geochemical, geotechnical suitability, Cement industry and Road base constructions.

\section{INTRODUCTION}

The study area lies between Latitudes $29^{\circ} 37^{\prime} 43^{\prime \prime}$ and $29^{\circ} 59^{\prime} 45^{\prime \prime} \mathrm{N}$. and longitudes $32^{\circ} 20^{\prime} 43^{\prime \prime}$ and $32^{\circ} 19^{\prime} 48^{\prime \prime}$ E (Fig, 1). It occupies the area between the northern scarp of the El-Galala El-Bahariya to the south and the Maadi- Sukhna road to the north. The stratigraphy of the area under consideration is established through a detailed study of Gebel Galala section which represents one or more stage of Lower Eocene. The section was measured at the best accessible exposure. The established stratigraphic column in the studied area is represented in (Fig. 2). Geologically little has been written on the geochemical, physical and mineralogical suitability of Lower Eocene carbonate rocks for road and cement industries ElQatamiya- Ain Sukhna road, Egypt (Haggag,1991; Strougo, et al., 1992; Bokhary, et al., 2002; Flugel, 2004; Issawi, et al., 2010; Selim, 2011; Tueckmantel, et al., 2010 and Loukina, et al 2018).

Lower Eocene carbonate, chemical, physical and mineralogical properties, were used in the present study to test their validity for road bases and cement industry. Carbonate has many uses; the most common uses are as base for roads (Armstrong, 2013; Dylan and Moore, 2014) and or as raw materials in cement industry (Salman, 2017). In the present study carbonate aggregate for road base construction and cement industries will be discussed. The surface, base, and sub base of pavements consist of aggregates. The suitability of carbonate rocks is estimated from a combination of experience, physical tests, and mineralogical examinations. (Tables 1 and 2, Figs. 3 to 6). Aggregate is a collective term for the mineral materials such as sand, gravel, and crushed stone that are used with a binding medium (such as water, bitumen, Portland cement, lime, etc.) to form compound materials (such as bituminous concrete and Portland cement concrete). 
Kamel, et al.

Fig. 1: Landsat image show the location map of the studied area.

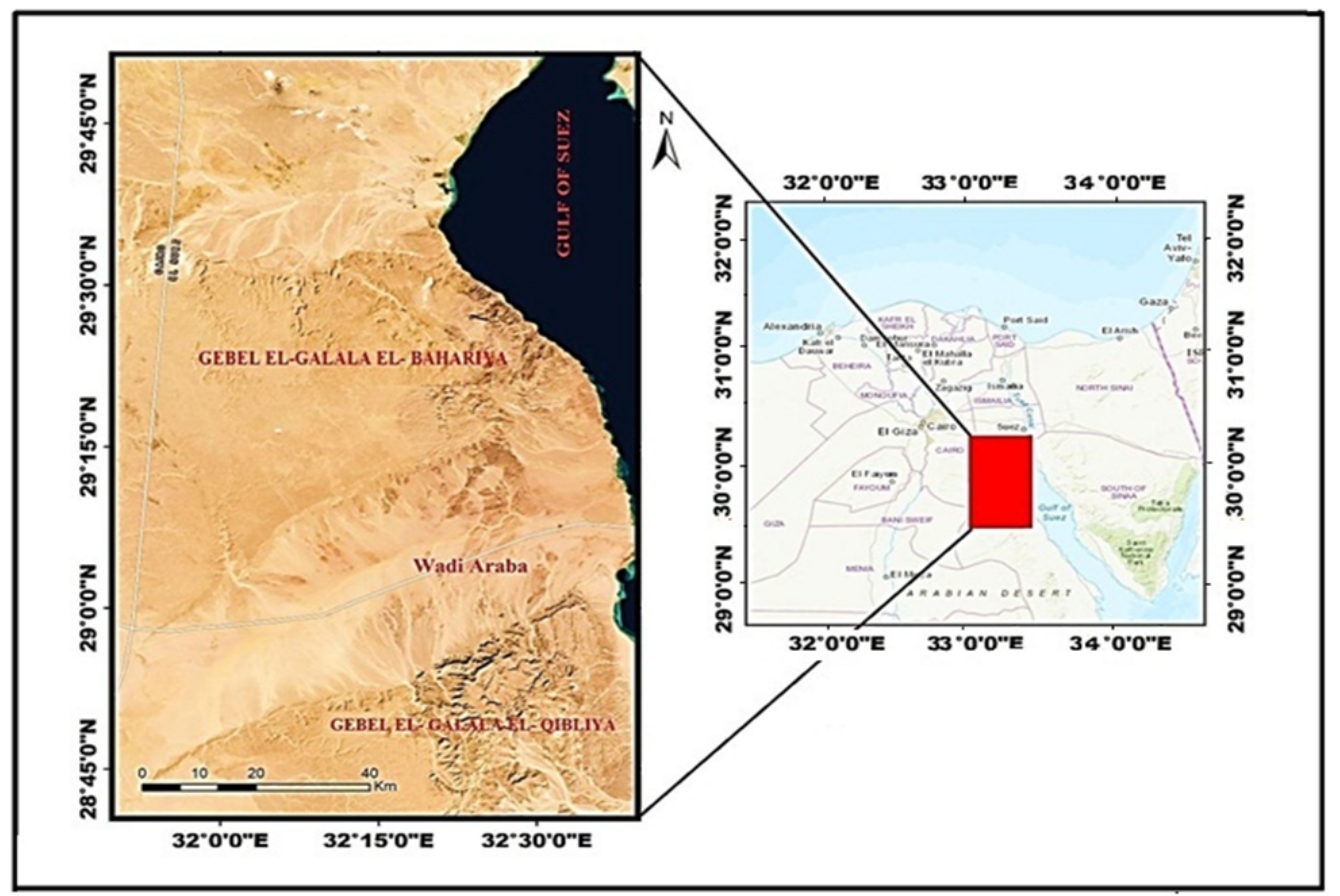

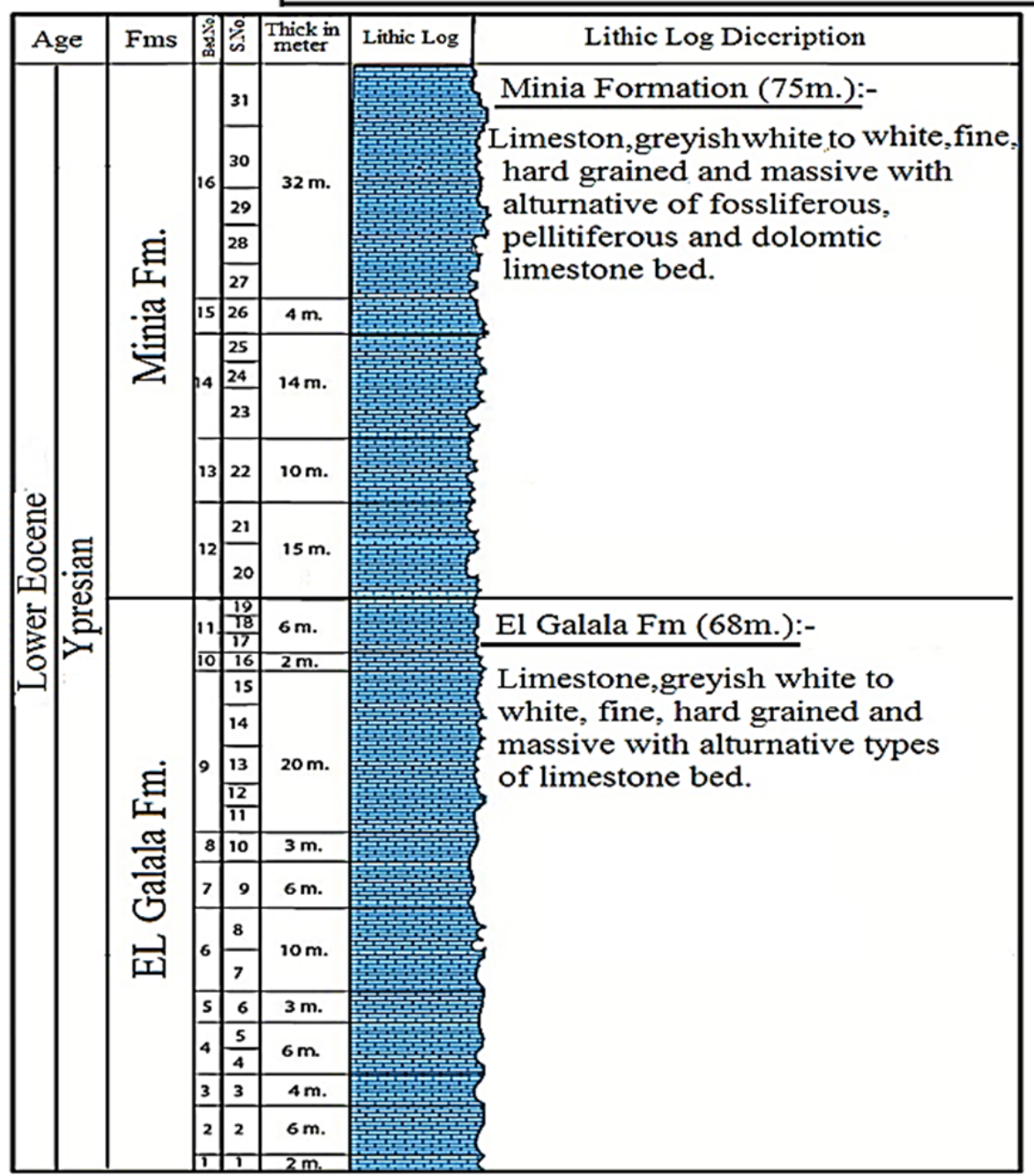

Fig. 2: Idealized composite columnar lithological section of Lower Eocene rock units (G. Galala section). 
Geochemical and geotechnical studies on carbonates

\section{METHDOLOGY}

Well-developed successions were measured and 31 samples were collected. Rock sub-units (beds) were defined in the field on the basis of superficial examination with a hand lens, aided in most cases by hydrochloric acid. Samples were taken, as a rule, not at regular intervals but insofar as possible from each stratigraphic sub-unit two or more samples were generally collected from sub-units thicker than 1 meter. The clastic and non-clastic rock samples were subjected to acid insoluble residue analysis. Physical properties were made (Crushing test is standardized by IS:2386 part-IV, Abrasion test according to (IS:2386 part-IV) method, Impact test according to IS : 2386 (Part 4)-1963 method, Shape test according to (IS:2386 part-I), Soundness test according to IS:2386 part-V method, Clay lumps according to IS : 6241-1971 method, Specific gravity and water absorption test according to IS: 2386 (Part 3)-1963) method on some raw materials (Limestone, Dolomite and Clay) (at Arab Contractor Company Labs ) detected in the studied area to test economic uses and their suitability for road base construction. Silica modulus (S. M) factor, Alumina ratio (A.R) and Lime saturation formula (L.S.F) was calculated by using equations to show the validity of the studied area to cement industry. From the collected samples 15 selected samples representing the clastic and non-clastic rock units were chemically analyzed after grinding, to determine the major oxides of $\mathrm{SiO}_{2}, \mathrm{Al}_{2} \mathrm{O}_{3}, \mathrm{Fe}_{2} \mathrm{O}_{3}, \mathrm{CaO}, \mathrm{MgO}, \mathrm{Na}_{2} \mathrm{O}, \mathrm{K}_{2} \mathrm{O}$ and $\mathrm{SO}^{3-}$, using XRay flourcense analysis (at National Research Center Labs).

\section{RESULTS AND DISCUSSIONS}

\section{Behavior of raw materials}

The availability of suitable raw materials is normally the determining factor in the location of cement works and these are normally located in close proximity to carbonate deposits and ideally close by other major raw materials (clay and gypsum) (McArthur, et. al 2014). Carbonates, clay, mudstone and shale deposits are common lithologies and are widely distributed in most parts of Egypt. Nevertheless, such sedimentary rocks may vary considerably in their chemistry and thickness and thus in their suitability for cement manufacture on a large scale. Generally, large quantities of a uniform source of calcium, silica, alumina and iron are required. The process of cement making is, however, remarkably flexible in terms of the raw materials that can be used to achieve required chemical compositions. Many carbonate deposits, provided they are low in $\mathrm{MgO}$, easily meet the requirements and a number of other $\mathrm{CaO}$-containing raw materials are known to be used. Alternative materials include marble, chalk, marl, shell deposits, blast furnace slag and alkali waste. The overburden to carbonate deposits is also used frequently as a source of silica, alumina and iron. Other mineral components (such as iron oxide wastes, silica sand, etc.) are sometimes used to blend into the raw material mix to optimize the chemistry.

\section{Rock aggregate in concrete}

\section{Crushing test}

One of the models in which pavement material can fail is by crushing under compressive stress. A test is standardized by IS: 2386 part-IV and used to determine the crushing strength of aggregates. The aggregate crushing value provides a relative measure of resistance to crushing under gradually applied crushing load. The test consists of subjecting the specimen of aggregate in standard mould to a compression test under standard load conditions (Fig. 3).

$$
\begin{array}{ll}
\text { Aggregate crushing value }=\frac{W_{1}}{W_{2}} \times 100 \quad \text { Equation } 1
\end{array}
$$

(W2) is expressed as percentage of the weight of the total sample (W1) which is the aggregate crushing value. A value less than 10 signifies an exceptionally strong aggregate while above 35 would normally be regarded as weak aggregates. 
Kamel, et al.

\section{Los Angeles Abrasion Value (LAAV) (Adaptation of AASHTO T 96-77)}

Abrasion test is carried out to test the hardness property of aggregates and to decide whether they are suitable for different pavement construction works. Los Angeles abrasion test is a preferred one for carrying out the hardness property and has been standardized in India (IS: 2386 part-IV). The principle of Los Angeles abrasion test is to find the percentage wear due to relative rubbing action between the aggregate and steel balls used as abrasive charge. This is a measurement of the resistance to attrition (Tables 1, 2 and Fig. 4).

$$
C=\frac{A-B}{A} X 100
$$

\section{Equation 2}

Where: -

A: Mass sample before test.

B: Mass sample after test.

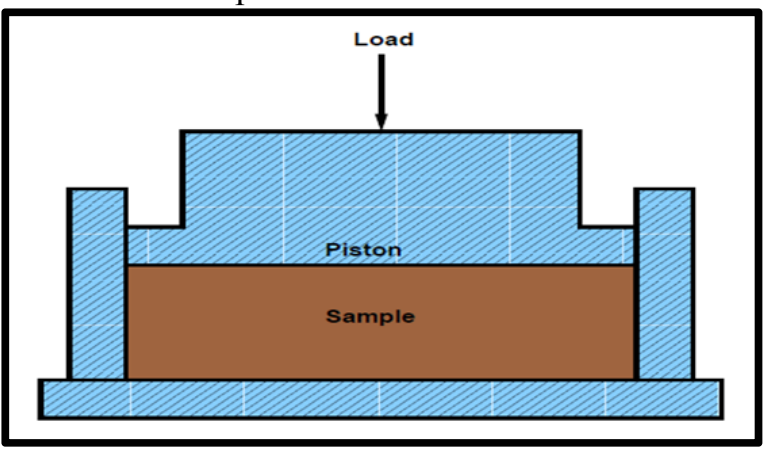

Fig. 3: Crushing test setup.

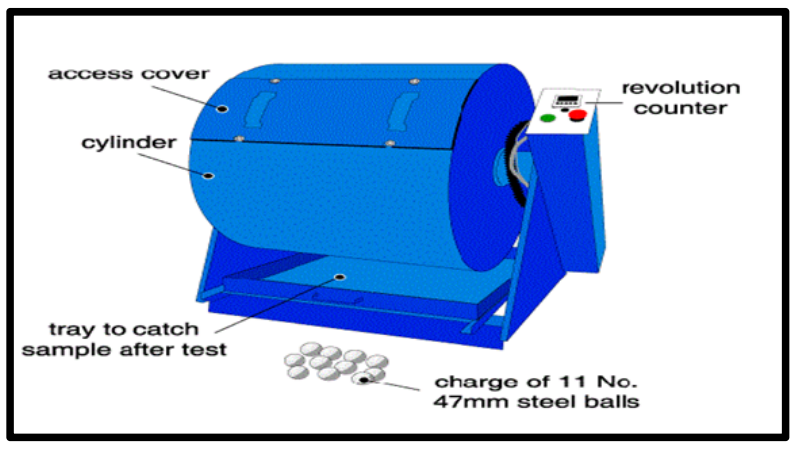

Fig. 4: Los Angeles Abrasion Machine

Aggregate is also used for base and sub-base courses for both flexible and rigid pavements. Aggregates can either be natural or manufactured. Natural aggregates are generally extracted from larger rock formations through an open excavation quarry).

\section{Desirable properties: -}

\section{Density Testing; (Adaptation of AASHTO T 85-77)}

The bulk density of construction aggregate is expressed as the weight per unit volume (Table 2).

\section{a. Bulk Specific Gravity}

$$
=\frac{A}{B-C}
$$

\section{$\underline{\text { Equation } 3}$}

\section{Where;}

A; mass of oven-dry sample in air, g.;

$\mathrm{B}=$ mass of saturated-surface-dry sample in air, g. and

$C$; mass of saturated sample in water, $g$.

\section{b. Bulk Specific Gravity (Saturated-Surface-Dry Basis)}

$=\frac{B}{B-C}$

\section{Equation 4}

c. Apparent Specific Gravity

$=\frac{A}{A-C}$

\section{$\underline{\text { Equation } 5}$}

d. Absorption

$=\frac{B-A}{A} X 100$

\section{Equation 6}


Geochemical and geotechnical studies on carbonates

Table 1: Results and average of physical properties of the studied Galala Fm.

\begin{tabular}{|c|c|c|c|c|c|c|c|c|c|}
\hline \multirow{2}{*}{\multicolumn{2}{|c|}{ S. No. }} & \multirow{2}{*}{$\begin{array}{c}\text { Impact } \\
\text { value } \%\end{array}$} & \multirow{2}{*}{$\begin{array}{l}\text { crushing } \\
\text { value } \%\end{array}$} & \multirow{2}{*}{$\begin{array}{c}\text { Abrasion } \\
\%\end{array}$} & \multicolumn{2}{|c|}{ Shape of Aggregates } & \multirow{2}{*}{$\begin{array}{c}\text { Accelerate } \\
\text { Polish \% }\end{array}$} & \multirow{2}{*}{$\begin{array}{c}\text { Soundness } \\
\%\end{array}$} & \multirow{2}{*}{$\begin{array}{c}\text { Clay } \\
\text { Lumps \% }\end{array}$} \\
\hline & & & & & Flaky & Elongated & & & \\
\hline & 1 & 18 & 33 & 17 & 6.8 & 4.5 & 95 & 2.7 & 0.20 \\
\hline & 2 & 19 & 36 & 15 & 7 & 3.7 & 96 & 2.5 & 0.25 \\
\hline & 3 & 25 & 22 & 18 & 7 & 4.2 & 95 & 2.4 & 0.21 \\
\hline & 4 & 16 & 15 & 16 & 5 & 5.3 & 95 & 2.5 & 0.17 \\
\hline & 5 & 22 & 17 & 15 & 6 & 4.4 & 95 & 2.3 & 0.21 \\
\hline & 6 & 24 & 28 & 14 & 7 & 6.5 & 96 & 3.0 & 0.23 \\
\hline & 7 & 17 & 29 & 15 & 8 & 7 & 95 & 3.3 & 0.24 \\
\hline & 8 & 22 & 22 & 18 & 4 & 6.2 & 95 & 4.0 & 0.27 \\
\hline & 9 & 18 & 36 & 20 & 6 & 5.5 & 95 & 2.4 & 0.23 \\
\hline & 10 & 19 & 32 & 19 & 4 & 4 & 96 & 2.3 & 0.24 \\
\hline & 11 & 18 & 18 & 18 & 7 & 5.9 & 95 & 2.7 & 0.21 \\
\hline & 12 & 19 & 19 & 16 & 5 & 6.5 & 95 & 3.5 & 0.20 \\
\hline & 13 & 19 & 25 & 15 & 3.5 & 7.7 & 95 & 4.0 & 0.20 \\
\hline & 14 & 33 & 26 & 12 & 6.7 & 5.7 & 96 & 4.2 & 0.23 \\
\hline & 15 & 17 & 27 & 21 & 4.7 & 5.7 & 95 & 4.6 & 0.21 \\
\hline & 16 & 14 & 35 & 22 & 2.5 & 5 & 95 & 2.5 & 0.21 \\
\hline & 17 & 22 & 38 & 17 & 4.9 & 5.3 & 95 & 3.2 & 0.24 \\
\hline & 18 & 28 & 40 & 19 & 5.2 & 5.1 & 96 & 3.1 & 0.23 \\
\hline & 19 & 29 & 15 & 20 & 5.7 & 5.5 & 95 & 3.5 & 0.40 \\
\hline \multicolumn{2}{|r|}{ Range } & $(14-33)$ & $(15-40)$ & $(12-22)$ & $(3.5-7)$ & $(3.7-7.7)$ & $(95-96) \%$ & $(2.4-3.5)$ & $(0.17-0.4)$ \\
\hline \multicolumn{2}{|r|}{ Average } & 21 & 27 & 17.2 & 5.6 & 5.5 & 95.3 & 3.1 & 0.24 \\
\hline \multirow{3}{*}{ 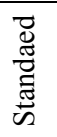 } & Base Coarse & Nil & Nil & $50 \%$ Max & \multicolumn{2}{|c|}{$10 \mathrm{Max}$} & 95 Min & 12Max & $5 \%$ \\
\hline & Asphalt & Nil & Nil & $40 \% \operatorname{Max}$ & \multicolumn{2}{|c|}{ 10Max } & 95 Min & 10 Max & Nil \\
\hline & Concrete & $35 \%$ Max & $45 \%$ Max & $30 \% \operatorname{Max}$ & \multicolumn{2}{|c|}{$25 \mathrm{Max}$} & $95 \mathrm{Min}$ & 18 Max & $3 \operatorname{Max}$ \\
\hline
\end{tabular}

Table 1. Cont. : Results and average of physical properties of the studied, Galala Fm.)

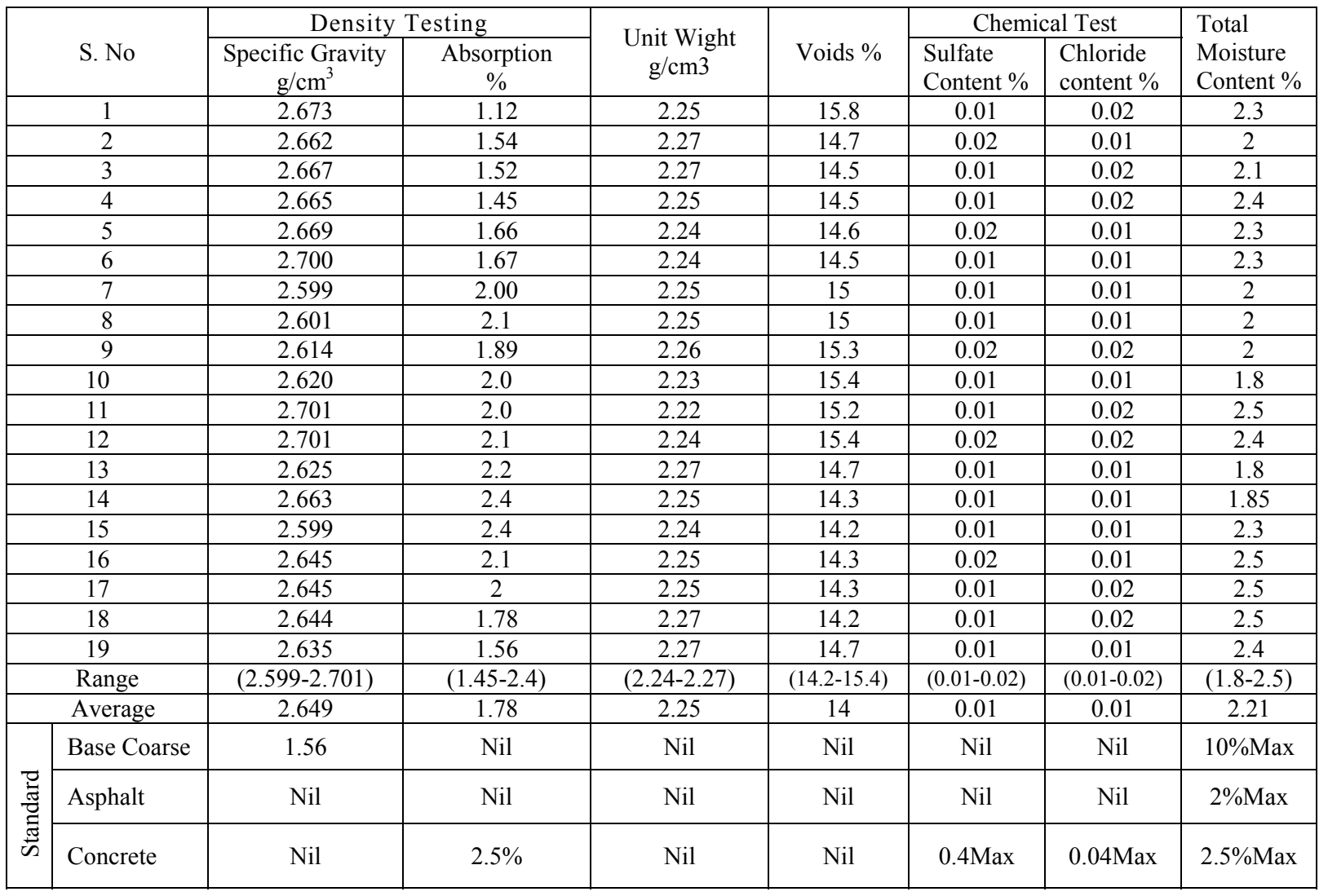


Kamel, et al.

Table 2: Results and average of physical properties of the studied, Minia Fm.

\begin{tabular}{|c|c|c|c|c|c|c|c|c|c|}
\hline \multirow{2}{*}{\multicolumn{2}{|c|}{ S. No. }} & \multirow{2}{*}{$\begin{array}{c}\text { Impact } \\
\text { value } \%\end{array}$} & \multirow{2}{*}{$\begin{array}{l}\text { crushing } \\
\text { value } \% \\
\end{array}$} & \multirow{2}{*}{ Abrasion \% } & \multicolumn{2}{|c|}{ Shape of Aggregates } & \multirow{2}{*}{$\begin{array}{c}\text { Accelerate } \\
\text { Polish \% }\end{array}$} & \multirow{2}{*}{$\begin{array}{c}\text { Soundne } \\
\text { Ss } \%\end{array}$} & \multirow{2}{*}{$\begin{array}{c}\text { Clay } \\
\text { Lumps \% }\end{array}$} \\
\hline & & & & & Flaky & Elongated & & & \\
\hline & 20 & 16 & 25 & 17 & 6.7 & 5.5 & 95 & 3.4 & 0.41 \\
\hline & 21 & 18 & 26 & 17 & 6.8 & 6 & 95 & 3.5 & 0.34 \\
\hline & 22 & 18 & 22 & 16 & 7 & 6.2 & 96 & 2.1 & 0.40 \\
\hline & 23 & 15 & 31 & 15 & 4.8 & 4.5 & 95 & 2.0 & 0.42 \\
\hline & 24 & 14 & 19 & 18 & 4.5 & 5 & 95 & 2.8 & 0.41 \\
\hline & 25 & 16 & 26 & 20 & 7.7 & 3.5 & 95 & 2.4 & 0.35 \\
\hline & 26 & 21 & 33 & 19 & 7.2 & 4.8 & 96 & 2.7 & 0.47 \\
\hline & 27 & 22 & 34 & 18 & 6.4 & 5.8 & 95 & 3.8 & 0.41 \\
\hline & 28 & 17 & 35 & 19 & 5.7 & 6.8 & 95 & 4.1 & 0.40 \\
\hline & 29 & 18 & 18 & 20 & 6.2 & 7 & 95 & 4.3 & 0.24 \\
\hline & 30 & 21 & 19 & 25 & 6.4 & 5.4 & 95 & 4.4 & 0.20 \\
\hline & 31 & 17 & 19 & 19 & 7.2 & r.o & 95 & 4.4 & 0.41 \\
\hline & Range & $(14-21)$ & $(18-35)$ & $(15-25)$ & 6.3 & 5.5 & $(95-96)$ & $(2-4.4)$ & $(0.2-0.47)$ \\
\hline & verage & $19 \%$ & $26 \%$ & $23.7 \%$ & $(4.5-6.8)$ & $(3.5-6.8)$ & $95.2 \%$ & $3.2 \%$ & $0.37 \%$ \\
\hline $\bar{z}$ & Base coarse & Nil & Nil & $50 \%$ Max & \multicolumn{2}{|c|}{$10 \mathrm{Max}$} & $95 \mathrm{Min}$ & 12Max & $5 \%$ \\
\hline छ్ & Asphalt & Nil & Nil & $40 \% \mathrm{Max}$ & \multicolumn{2}{|c|}{ 10Max } & 95 Min & 10 Max & Nil \\
\hline & Concrete & $35 \% \mathrm{Max}$ & $45 \% \mathrm{Max}$ & $30 \%$ Max & \multicolumn{2}{|c|}{$25 \mathrm{Max}$} & 95 Min & $18 \mathrm{Max}$ & 3 Max \\
\hline
\end{tabular}

Table 2 Cont.: Results and average of physical properties of the studied Minia Fm.

\begin{tabular}{|c|c|c|c|c|c|c|c|c|}
\hline & \multirow[b]{2}{*}{ S. No } & \multicolumn{2}{|c|}{ Density Testing } & \multirow[b]{2}{*}{$\begin{array}{l}\text { Unit Wight } \\
\mathrm{g} / \mathrm{cm}^{3}\end{array}$} & \multirow[b]{2}{*}{ Voids \% } & \multicolumn{2}{|c|}{ Chemical Test } & \multirow[b]{2}{*}{$\begin{array}{c}\text { Total } \\
\text { Moisture Content } \\
\%\end{array}$} \\
\hline & & $\begin{array}{l}\text { Specific } \\
\text { Gravity } \\
\mathrm{g} / \mathrm{cm} 3\end{array}$ & $\begin{array}{c}\text { Absorpti } \\
\text { on } \\
\% \\
\end{array}$ & & & $\begin{array}{c}\text { Sulfate } \\
\text { Content } \\
\% \\
\end{array}$ & $\begin{array}{c}\text { Chloride content } \\
\% \%\end{array}$ & \\
\hline & 20 & 2.645 & 1.7 & 2.22 & 15.0 & 0.02 & 0.02 & 2.3 \\
\hline & 21 & 2.678 & 2.3 & 2.23 & 15.4 & 0.01 & 0.02 & 2.2 \\
\hline & 22 & 2.652 & 2.0 & 2.22 & 15.3 & 0.01 & 0.01 & 2.2 \\
\hline & 23 & 2.632 & 2.2 & 2.22 & 15.1 & 0.02 & 0.01 & 2.1 \\
\hline & 24 & 2.645 & 2.1 & 2.24 & 14.2 & 0.01 & 0.01 & 2.4 \\
\hline & 25 & 2.635 & 2.0 & 2.27 & 14.3 & 0.02 & 0.01 & 2.5 \\
\hline & 26 & 2.651 & 2.0 & 2.26 & 14.2 & 0.01 & 0.02 & 2.5 \\
\hline & 27 & 2.652 & 2.0 & 2.25 & 14.2 & 0.01 & 0.02 & 2.4 \\
\hline & 28 & 2.654 & 2.2 & 2.25 & 14.8 & 0.02 & 0.01 & 2.4 \\
\hline & 29 & 2.653 & 2.3 & 2.26 & 15.1 & 0.01 & 0.01 & 2.4 \\
\hline & 30 & 2.641 & 2.1 & 2.27 & 15 & 0.02 & 0.02 & 2.1 \\
\hline & 31 & 2.645 & 2.0 & 2.22 & 14.3 & 0.02 & 0.01 & 2.4 \\
\hline & Range & $(2.641-678)$ & $(1.7-2.3)$ & $(2.22-2.27)$ & $(14.2-15.4)$ & $(0.01-0.02)$ & $(0.01-0.02)$ & $(2.1-2.5)$ \\
\hline \multicolumn{2}{|r|}{ Average } & 2.649 & $2.1 \%$ & 2.24 & $14.8 \%$ & $0.01 \%$ & $0.01 \%$ & $2.3 \%$ \\
\hline \multirow{3}{*}{ D } & Base Coarse & Nil & Nil & Nil & Nil & Nil & Nil & $10 \% \operatorname{Max}$ \\
\hline & Asphalt & Nil & Nil & Nil & Nil & Nil & Nil & $2 \% \operatorname{Max}$ \\
\hline & Concrete & Nil & $2.5 \%$ & Nil & Nil & $0.4 \mathrm{Max}$ & $0.04 \mathrm{Max}$ & $2.5 \% \mathrm{Max}$ \\
\hline
\end{tabular}

\section{Strength}

Strength tests are used to assess the suitability of aggregate for use in road stone or concrete. They are indicator tests, measuring the likely rather than the actual performance of aggregate.

\section{A. $\quad$ Aggregate Impact Value (AIV):(Adaptation of BS 812: Part 110: 1990)}

The aggregate impact test is carried out to evaluate the resistance to impact of aggregates, this is the measurement of the aggregate's resistance to repeated and sudden force. The lower the AIV, the stronger the aggregate. An AIV less than 30 is usually required (Table 1).

$A I V=\frac{M 2}{M 1} X 100$

\section{Equation 7}

Where:

M1 is the mass of the test specimen (in gram)

M2 is the mass of the material passing the $2.36 \mathrm{~mm}$ test sieve (in gram). 
Geochemical and geotechnical studies on carbonates

\section{B. Aggregate Crushing Value (ACV) (Adaptation of BS 812: Part 112: 1990)}

This is the measurement of the resistance of aggregate to crushing by compressive force. The higher the value the weaker the aggregate. An ACV greater than 35\% indicates that aggregate is too weak for most construction uses (Table 1).

$$
A C V=\frac{M 1}{M 2} X 100
$$

\section{Equation 8}

Where:

M1 is the mass of the test specimen (in gram);

$\underline{\mathrm{M} 2}$ is the mass of the material passing the $2.36 \mathrm{~mm}$ test sieve (in gram)

Shape of aggregates; (Adaptation of ASTM D 4791 - 05)

The particle shape of the aggregate mass is determined by the percentage of flaky and elongated particles in it. Aggregates which happen to fall in a particular size range may have rounded cubical, angular, flaky or elongated particles. It is evident that the flaky and elongated particles will have less strength and durability when compared with cubical, angular or rounded particles of the same aggregate. Hence too flaky and too much elongated aggregates should be avoided as far as possible (Table 1).

$$
\begin{aligned}
& \text { Flat Particles Percent }=\frac{\text { Mass of Flat }}{\text { Test Portion Mass }} X 100 \quad \underline{\text { Equation 9 }} \\
& \text { Elongated Particles Percent }=\frac{\text { Mass of elongate }}{\text { Test Portion Mass }} X 100 \quad \underline{\text { Equation } 10}
\end{aligned}
$$

Fig. 5: Flakiness gauge.
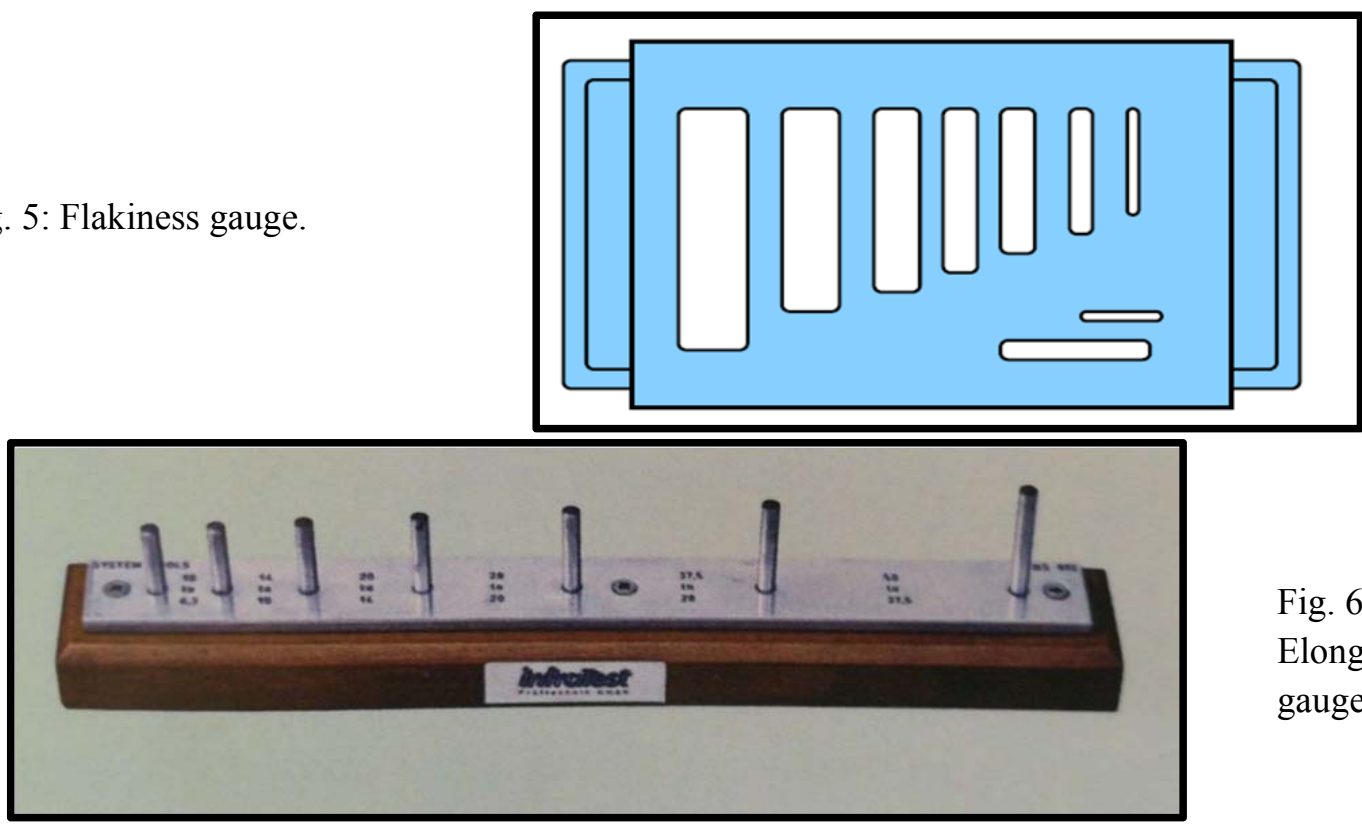

Fig. 6:

Elongation gauge.

\section{Adhesion with bitumen (accelerated polish); (Adaptation of AASHTO T 182-84)}

The aggregates used in bituminous pavements should have less affinity with water when compared with bituminous materials, otherwise the bituminous coating on the aggregate will be stripped of in presence of water. Material should be passing $3 / 8$ " and retained on $1 /{ }^{\prime \prime}$ sieves, from the Hot-bin combined Aggregates washed and dried to a constant mass at $110 \pm 5 \mathrm{C}^{\circ}$. Coating: Weigh $100 \mathrm{~g}$ of oven dry sample in to the mixing container. When testing asphalt, place the container containing the aggregate in a 135 $149 \mathrm{C}^{\circ}$ constant temperature oven for one hour. Heat the asphalt separately to $135-149 \mathrm{C}^{\circ}$. Add $5.5 \pm 0.2$ $\mathrm{g}$ of the heated Bitumen to the hot aggregate. Warm the spatula blade and mix vigorously with the spatula for 2 to 3 minutes or until the aggregate is completely coated, allowing the temperature of the contents of the container to drop naturally during the mixing. After the coating allow the mixture to cool to room temperature. Water Immersion: Transfer their coated aggregate to a $600 \mathrm{ml}$ glass container. Cover 
Kamel, et al.

immediately with $400 \mathrm{ml}$ of distilled water at room temperature (approximately $25 \mathrm{C}^{\circ}$ ). Soak the Bituminous coated aggregate in the water for 16 to 18 hours. Visual Estimation: Without disturbing or agitating the coated aggregate remove any film floating on the water surface. Any thin brownish, translucent areas are to be considered fully coated.

\section{Durability (Soundness testing); (Adaptation of AASHTO T 104-77)}

Soundness test is intended to study the resistance of aggregates to weathering action, by conducting accelerated weathering test cycles. Soundness testing is used to identify those aggregate that may be prone to degradation in saturated moisture conditions, elevated temperatures or freezing conditions. Magnesium Sulfate Soundness Value (MSSV) - this measures the breakdown of aggregates following accelerated physical weathering by salt crystallization. Repeated cycles of immersion of aggregate (10$14 \mathrm{~mm}$ ) in magnesium sulfate solution and oven drying simulate the expansion of water on freezing. The weight loss proportion is calculated as the MSSV (Table 1).

$$
=\frac{G}{A} X 100 \quad \underline{\text { Equation } 11}
$$

Whereas; $\mathrm{G}=\mathrm{F} \times \mathrm{A} / 100 ; \mathrm{F}=\mathrm{E} / \mathrm{B} \times 100$ and $\mathrm{E}=\mathrm{B}-\mathrm{D}$

(G): Total corrected average \% Loss. (A): Total Original Grading \%

(F): Loss in Mass after test \% $\quad$ (E): Loss in Mass after test

$\begin{array}{ll}\text { (B) Mass of sample. before test, } & \text { (D): Mass of sample after test, g }\end{array}$

Freedom from Deleterious Particles (clay lumps); (Adaptation of AASHTO T 112-80)

Specifications for aggregates used in bituminous mixes usually require the aggregates to be clean, tough and durable in nature and free from excess amount of elongated pieces, dust, clay balls and other objectionable material. Similarly aggregates used in Portland cement concrete mixes must be clean and free from deleterious substances such as clay lumps (Table 1).

$=\frac{W-R}{W} X 100$

\section{$\underline{\text { Equation } 12}$}

Where:

$\mathrm{P}=$ percent of clay lumps;

$\mathrm{W}=$ Fraction mass of test sample and

$\mathrm{R}=$ mass of particles retained on designated sieve.

Unit Weight and Voids in Aggregates (Adaptation of AASHTO T 19-80 and T 20-42)

This is a measure of how well an aggregate will pack together or consolidate. How well a material will pack together is dependent on the amount of air space, or voids, left around the aggregate particles (Tables 1 and 2).

$$
\text { Unit Weight }=\frac{H}{F}
$$

\section{Equation 13}

Where:

$\mathrm{H}$; Mass of Sample and

$\mathrm{F}$; volume of container

Void Content in Aggregate

$$
\mathrm{V}=\frac{(s \times w)-u}{(s \times w)} \times 100
$$

\section{$\underline{\text { Equation } 14}$}

Where:

S: bulk specific gravity of the aggregate;

$\mathrm{U}$ : unit mass of aggregate and

$\mathrm{W}$ : unit mass of water. 
Geochemical and geotechnical studies on carbonates

\section{Chemical Test}

1. Sulfate Content in Aggregate; (Adaptation of AASHTO T 290-95)

$$
\mathrm{SO}^{-3}=\frac{W X 0.41158 \times 100}{\text { weight of sample }}
$$

$\underline{\text { Equation } 15}$

Where; $\mathrm{W}=\mathrm{g}$, barium sulfate (mass after ignition) (Table 2).

\section{Soluble chloride Content; (Adaptation of AASHTO T 291-94)}

These methods are applicable to the determination the soluble chlorides in aggregate road materials.

$$
\mathrm{CI}^{-} \%=\frac{\text { MI Of AgNO3Xfactor of } \mathrm{AgNO3}}{\text { Wt.in aliquot }} \times 100 \quad \underline{\text { Equation } 16}
$$

Total Moisture Content of Coarse Aggregate; (Adaptation of AASHTO T 255-76)

This method covers the determination of the percent moisture content, both surface in a sample of aggregate by drying.

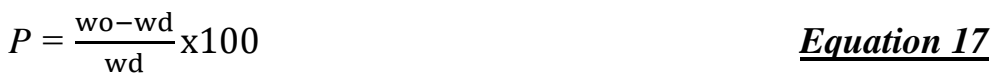

Whereas; $p$; moisture content of percent; Wo; weight of sample before $110 \mathrm{C}^{\mathrm{O}}$

And $\mathrm{Wd}$; weight of sample after110 $\mathrm{C}^{\mathrm{O}}$

\section{CEMENT RAW MATERIALS}

\section{Minerals and Chemical composition}

The purpose of the present work is to show how composition of raw mix for cement quality depends on minerals and chemical composition.

\section{Definition and Mineralogy}

The present definition of a cement as given in German standard, (McArthur, et al 2014) is as follows:" Cement is a finally ground hydraulic binding medium for mortar and concrete consisting substantially of compounds calcium oxide with silicon dioxide, aluminum oxide and ferric oxide. It is formed by sintering and fusion, by heating of a mixture of carbonate and clay, or other materials of similar bulk composition in Portland cement clinker with an admixture of sulfate (Robert, 2004 and Ibrahim, et al., 2015). Cement is a manufactured product made by blending different raw materials and firing them at a high temperature in order to achieve precise chemical proportions of lime, silica, alumina and iron in the finished product, known as cement clinker. Cement is therefore essentially a mixture of calcium silicates and smaller amounts of calcium aluminates that react with water and cause the cement to set. The requirement for calcium is met by using high calcium carbonate (or its equivalent calcareous raw material) and clay, mudstone or shale as the source of most of the silica and alumina. Finished cement is produced by finely grinding together around 95\% cement clinker with 5\% gypsum (or anhydrite) which helps to retard the setting time of the cement. The quality of cement clinker is directly related to the chemistry of the raw materials used. Around 80 to $90 \%$ of raw material for the kiln feed is carbonate.

Clay raw material accounts for between 10 to 15 percent, although the precise amounts will vary. Magnesium carbonate, which may be present in carbonate, is the main undesirable impurity. The level of magnesium oxide $(\mathrm{MgO})$ in the clinker should not exceed $5 \%$ and many producers favour a maximum of $3 \%$; this rule out dolomite or dolomitic carbonates for cement manufacture. Other deleterious materials include excessive alkalis (sodium oxide, $\mathrm{Na}_{2} \mathrm{O}$ and potassium oxide, $\mathrm{K}_{2} \mathrm{O}$ ) which would be unacceptable because of durability problems with the concrete (due to the reaction of alkalis with some siliceous aggregates to form a swelling gel). Portland cement is the most widely produced cement. Blended cements are produced by finely grinding Portland cement clinker with other constituents, such as blast furnace slag, natural silica fume, meta-kaolin, siliceous fly ash, calcareous fly ash, carbonate fines and shale. 
Kamel, et al.

\section{Cement manufacturing}

Cement clinker is made by heating the blended and ground raw material (typically carbonate and clay or shale and other materials) to partial fusion. The clinker burning (Ibrahim, et al., 2015) takes place at a temperature of $1450^{\circ} \mathrm{C}$ in kilns, which are normally inclined rotating cylinders lined with heat-resistant bricks. Clinker emerges from the kiln after several hours as granulated spherical pebbles. Afterwards, the clinker is finely ground by ball milling with a small amount (typically 5\%) of gypsum/anhydrite to give Portland cement. Gypsum/anhydrite is introduced to control the initial rate of reaction with water and to allow concrete to be placed and compacted before hardening commences.

Blended cements are produced by intergrading cement clinker with materials like fly ash, granulated blast furnace slag, carbonate dust, natural (e.g. volcanic ash) or artificial (e.g. meta-kaolin), in addition to gypsum/anhydrite.

Most national specifications (Ibrahim, et al., 2015). for Portland cement require that the cement should not contain more than $5 \% \mathrm{MgO}$ (less than $3 \%$ in the carbonate raw material); therefore, identification of dolomite is crucial in the evaluation of carbonate rocks for cement manufacture. Other chemical specifications may limit Sulphur trioxide $\left(\mathrm{SO}_{3}\right)$ and phosphorus pent oxide $\left(\mathrm{P}_{2} \mathrm{O}_{5}\right)$ to less than $1 \%$ and total alkalis to less than $0.6 \%$. Additional specifications may apply to specialty cement types, such as sulphateresisting cement, oil-well cement and white cement (for example, less than $0.01 \% \mathrm{Fe}_{2} \mathrm{O}_{3}$ ).

\section{Raw Material Calculation}

Suppose the degree of purity of $\mathrm{CaO}$ in carbonate $96 \%$ and $4 \%$ clays to gain from them $\mathrm{CaO} \%$ amount equal to $65 \%$ in the clinker. To gain $100 \mathrm{Kg}$. of $\mathrm{CaO}$ from carbonate and clays, calculation according to the following formula must be done (Ibrahim, et al 2015).

$$
\begin{aligned}
& \mathrm{Z}=100(\mathrm{P}-\mathrm{Y})=100(0.04-0.65)=61 \mathrm{Kg} . \quad \text { Equation } \\
& =\mathrm{P}-\mathrm{Q} \quad=0.04-0.96
\end{aligned}
$$

Where:

$\mathbf{Z}$ ( $\mathrm{CaO} \%$ of both carbonate and clays supposed to use in clinker).

$\mathbf{P}(\mathrm{CaO} \%$, the degree of purity of $\mathrm{CaO}$ in clay sample).

$\mathbf{Y}(\mathrm{CaO} \%$ recorded carbonate sample supposed to use in clinker).

$\mathbf{Q}(\mathrm{CaO} \%$ the degree of purity of $\mathrm{CaO}$ in carbonate $)$.

According to the previous equation and to gain $100 \mathrm{Kg}$. of $\mathrm{CaO}$ we must use an amount equal to $61 \%$ of $\mathrm{CaO}$ (from carbonate after burning to $1000 \mathrm{C}^{\circ}$ ) and $39 \%$ of $\mathrm{CaO}$ (from clay after burning to $1000 \mathrm{C}^{\circ}$ ).

\section{The Clinker Process}

The burning of cement clinker consists of a series of reactions between chemically dissimilar finely divided particles. In general, the reactions can be listed as follow; evaporation of the free water, loss of combined water from clay minerals and combination between lime and clays. The reactions may be formulated as shown in (Table 3 and Fig. 7).

Table 3: Reactions occurring in Rotary Kiln, (Dylan and Moore 2014).

\begin{tabular}{|l|l|}
\hline Temperature $\mathrm{C}^{0}$ & Reaction Type \\
\hline $20-100 \mathrm{C}^{\mathrm{o}}$ & Loss of free water (moisture) \\
\hline $100-300 \mathrm{C}^{\mathrm{o}}$ & Loss of adsorbed water (clays) \\
\hline $400-900 \mathrm{C}^{\mathrm{o}}$ & Loss of combined water (L.O. I) \\
\hline$>500 \mathrm{C}^{\mathrm{o}}$ & Meta-kaolin formation \\
\hline $600-900 \mathrm{C}^{\mathrm{o}}$ & Carbonate destruction (calcination) \\
\hline$>800 \mathrm{C}^{\mathrm{o}}$ & Belite $\left(\mathrm{B}-\mathrm{C}_{2} \mathrm{~S}\right)$, Aluminates $\left(\mathrm{C}_{3} \mathrm{~A}\right)$ and Celite $\left(\mathrm{C}_{4} \mathrm{AF}\right)$ formation \\
\hline$>125 \mathrm{o}$ Co & Formation of Alite $\left(\mathrm{C}_{3} \mathrm{~S}\right)$. Aluminates and Celite dissolved \\
\hline $1450 \mathrm{Co}$ & Reactions are complete. Alite and Belite recrystallized. \\
\hline $1300-1240 \mathrm{Co}$ & Recrystallization of soluble Celite and Aluminates \\
\hline
\end{tabular}


Geochemical and geotechnical studies on carbonates

Fig. 7: Typical reactions and constituents of Portland clinker (Dylan and Moore 2014).

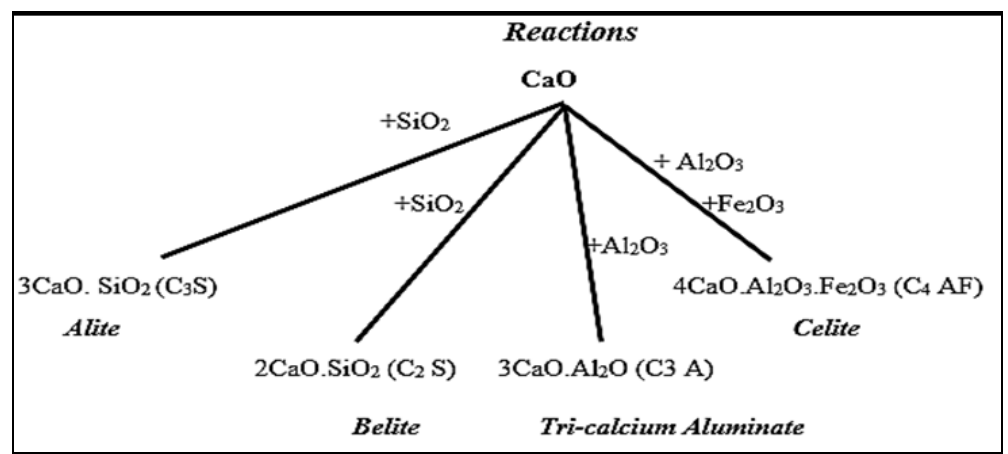

\section{Calculation of clinker phases}

Clinker four phases (Dylan and Moore, 2014) can be written in abbreviation forms as follows;

$$
\mathrm{CaO}=\mathrm{C}, \mathrm{SiO}_{2}=\mathrm{S}, \mathrm{Al}_{2} \mathrm{O}_{3}=\mathrm{A} \text { and } \mathrm{Fe}_{2} \mathrm{O}_{3}=\mathrm{F} \text {. }
$$

1- $4 \mathrm{CaO} \cdot \mathrm{Al}_{2} \mathrm{O}_{3} \cdot \mathrm{Fe}_{2} \mathrm{O}_{3}=\mathrm{C}_{4} \mathrm{AF}$. Celite

2- $3 \mathrm{CaO} . \mathrm{Al}_{2} \mathrm{O}_{3}=\mathrm{C}_{3} \mathrm{~A}$. Tri-calcium Aluminate

3- B -2CaO. $\mathrm{SiO}_{2}=\mathrm{B}-\mathrm{C}_{2} \mathrm{~S}$. Belite

4- $3 \mathrm{CaO} . \mathrm{SiO}_{2}=\mathrm{C}_{3} \mathrm{~S}$. Alite

To determine the phases percent in analyzed samples use the following rules: -

1 - To determine $\mathrm{CaO}$ used in the formation of anhydrite $\left(\mathrm{CaSO}_{4}\right)$ mineral, multiply the $\mathrm{SO}_{3}$ content by 0.7 (factor). Reduce the total amount of $\mathrm{CaO}$ by an amount equal to $\mathrm{CaO}$ used.

2- To determine $\mathrm{CaO}$ used in the formation of Celite, $\mathrm{C}_{4} \mathrm{AF}\left(4 \mathrm{CaO} . \mathrm{Al}_{2} \mathrm{O}_{3} . \mathrm{Fe}_{2} \mathrm{O}_{3}\right)$, multiply all the amount of $\mathrm{FeO} 3$ content by 1.41 (factor) and $\mathrm{Al}_{2} \mathrm{O}_{3}$ content by 2.20 (factor). Reduce the total amount of $\mathrm{CaO}$ by an amount equal to $\mathrm{CaO}$ used. Reduce the total amount of $\mathrm{Al}_{2} \mathrm{O}_{3}$ by an amount equal to $\mathrm{Al}_{2} \mathrm{O}_{3}$ used.

3- To determine $\mathrm{CaO}$ used in the formation of Tri-calcium Aluminate, $\mathrm{C} 3 \mathrm{~A}\left(3 \mathrm{CaO} . \mathrm{Al}_{2} \mathrm{O}_{3}\right)$, multiply all the amount of $\mathrm{Al}_{2} \mathrm{O}_{3}$ content by 1.65 (factor) Reduce the total amount of $\mathrm{CaO}$ by an amount equal to $\mathrm{CaO}$ used. Reduce the total amount of $\mathrm{Al}_{2} \mathrm{O}_{3}$ by an amount equal to $\mathrm{Al}_{2} \mathrm{O}_{3}$ used.

4- To determine $\mathrm{CaO}$ used in the formation of Belite, $\mathrm{C}_{2} \mathrm{~S}\left(2 \mathrm{CaO}\right.$. $\left.\mathrm{SiO}_{2}\right)$. Multiply the amount of $\mathrm{SiO}_{2}$ content by 1.87 (factor). Reduce the total amount of $\mathrm{CaO}$ by an amount equal to $\mathrm{CaO}$ used. Reduce the total amount of $\mathrm{SiO}_{2}$ by an amount equal to $\mathrm{SiO}_{2}$ used.

5- To determine $\mathrm{CaO}$ used in the formation of Alite, $\mathrm{C} 3 \mathrm{~S}\left(3 \mathrm{CaO} . \mathrm{SiO}_{2}\right)$. Multiply the amount of $\mathrm{SiO}_{2}$ content by 2.80 (factor). Reduce the total amount of $\mathrm{CaO}$ by an amount equal to $\mathrm{CaO}$ used. Reduce the total amount of $\mathrm{SiO}_{2}$ by an amount equal to $\mathrm{SiO}_{2}$ used.

\section{Properties of Cement Phases}

According to (Ibrahim, et al., 2015) (Table 4); Alite $\left(\mathrm{Ca}_{3} \mathrm{SiO}_{5}\right)$ is the most important constituent of all normal Portland cement clinkers for strength development; it reacts relatively quickly with water and consists of $50-70 \%$ tri-calcium silicate. Silicate modified in composition and crystal structure by ionic substitutions. Belite $\left(\mathrm{Ca}_{2} \mathrm{SiO}_{4}\right)$ constitutes $15-30 \%$ of normal Portland cement clinkers. It is di -calcium silicate modified by ionic substitutions. It reacts slowly with water, thus contributing little to the strength during the first 28 days, but substantially to the further increase in strength that occurs at later ages. The strengths obtainable from pure Alite and pure Belite are about the same under comparable conditions.

Aluminate $\left(\mathrm{Ca}_{3} \mathrm{Al}_{2} \mathrm{O}_{6}\right)$ constitutes $5-10 \%$ of most normal Portland cement clinkers. It is tri-calcium aluminate substantially modified in composition and sometimes also in structure by ionic substitution.

\section{Calculations of some important factors}

Three factors affect the quality of raw mixes and also on the crystalline constituents of clinker; lime saturation factor (L.S.F.), silica modulus (S.M) and Alumina Iron ratio A/F. 
Kamel, et al.

Table 4: Properties of the major constituents of Portland cement (Dylan and Moore, 2014).

\begin{tabular}{|c|c|c|c|c|}
\hline Compound & A Alite (C3S) & B Belite(C2S) & Aluminate(C3A) & Celite (C4AF) \\
\hline $\begin{array}{l}\text { Chemical } \\
\text { Composition }\end{array}$ & $3 \mathrm{CaO} \cdot \mathrm{SiO}_{2}$ & $2 \mathrm{CaO} \cdot \mathrm{SiO}_{2}$ & $3 \mathrm{CaO} \cdot \mathrm{Al}_{2} \mathrm{O}_{3}$ & $4 \mathrm{CaO} \cdot \mathrm{Fe}_{2} \mathrm{O}_{3} \cdot \mathrm{Al}_{2} \mathrm{O}_{3}$ \\
\hline Rate of Hydration & Rapid (hours) & Slow (days) & Instantaneous & very rapid(min) \\
\hline $\begin{array}{l}\text { Strength } \\
\text { Development }\end{array}$ & Rapid (days) & Slow (weeks) & $\begin{array}{l}\text { Very rapid (one } \\
\text { day) }\end{array}$ & very rapid (one day) \\
\hline Ultimate Strength & High: tens $\mathrm{N} / \mathrm{mm}^{2}$ & Probable: tens N/mm ${ }^{2}$ & Low: few $\mathrm{N} / \mathrm{mm}^{2}$ & Low: few $\mathrm{N} / \mathrm{mm}^{2}$ \\
\hline Heat of Hydration & Medium $530 \mathrm{~J} / \mathrm{g}$ & Low $250 \mathrm{~J} / \mathrm{g}$ & Very High $850 \mathrm{~J} / \mathrm{g}$ & Medium $420 \mathrm{~J} / \mathrm{g}$ \\
\hline Remarks & $\begin{array}{l}\text { Characteristic } \\
\text { constituent of } \\
\text { Portland Cement }\end{array}$ & $\begin{array}{l}\text { Characteristic } \\
\text { constituent. } \\
\text { of low heat P.C }\end{array}$ & $\begin{array}{l}\text { Unstable in water, } \\
\text { Sensitive to } \\
\text { sulphates attack }\end{array}$ & $\begin{array}{l}\text { Imparts to the cement. } \\
\text { Its characteristic grey } \\
\text { color. }\end{array}$ \\
\hline
\end{tabular}

\section{The effect of lime saturation (L.S.F.)}

This ratio affects the relative potential proportions of Alite and belite. Increasing clinker L.S.F at constant free lime, increase the quality of Alite at the expense of belite. Lime saturation formula (L.S.F) factor in Portland cement must do not exceed than 1.02 and not less than 0.66 .

$$
\text { Lime saturation formula (L.S.F) }=\frac{\mathrm{CaO}-0.7(\mathrm{SO} 4)}{2.8 \mathrm{SiO} 2+1.2 \mathrm{Al} 2 \mathrm{O} 3+0.65 \mathrm{Fe} 2 \mathrm{O} 3}
$$

\section{The effect of silica modulus (S.M.)}

The major effect of S.M. is on the quantity of flux or liquid potentially present at clinkering temperature. At low S.M. the quantity of liquid is high and vice versa. Reducing the quantity of liquid by increasing S.M., increases the proportion of silicate and at constant L.S.F., this means the increase of Alite quantity. Silica modulus (S.M) factor in Portland cement reveals that ranges from 1.7 to2.0 for low silica cement and from 2.5 to 3.5 for high silica cement. In Portland cement factor range from 2.0 to 2.5.

$$
\text { Silica modulus (S.M) }=\frac{\mathrm{SiO} 2}{\mathrm{Al} 2 \mathrm{O} 3+\mathrm{Fe} 2 \mathrm{O} 3}
$$

\section{The effect of Alumina Iron ratio A/F}

The flux consists potentially of $\mathrm{C}, \mathrm{A}$ and ferrite with small quantities of silica, magnesia, lime and alkalis. The higher the $\mathrm{A} / \mathrm{F}$ ratio the greater is the proportion of $\mathrm{Al}_{2} \mathrm{O}_{3}$ relative to $\mathrm{Fe}_{2} \mathrm{O}_{3}$. The viscosity of the flux is affected by the composition; the higher ratio gives more viscosity. The factor detects the ratio between $\mathrm{Al}_{2} \mathrm{O}_{3}$ and $\mathrm{Fe}_{2} \mathrm{O}_{3}$.

$$
\text { Alumina ratio (A.R) }=\frac{\mathrm{Al} 2 \mathrm{O} 3}{\mathrm{Fe} 2 \mathrm{O} 3}
$$

The following paragraphs deals with results (Tables 3, 4 and 5) of the studies area: To calculate the ratio of carbonate and clay used in Portland cement industry supposes that the purity degree of carbonate is $96 \% \mathrm{CaO}$ or the required carbonate saturation fact (L.S.F) of the mixed bed is 0.96 .

So, when the L.S.F equal one, the factor for $\mathrm{SiO}_{2}, \mathrm{Al}_{2} \mathrm{O}_{3}$ and $\mathrm{Fe}_{2} \mathrm{O}_{3}$ are 2.8, 1.2 and o.65 respectively. To calculate the modified factors of $\mathrm{SiO}_{2}, \mathrm{Al}_{2} \mathrm{O}_{3}$ and $\mathrm{Fe}_{2} \mathrm{O}_{3}$; each factor must be multiplied by 0.96 .

$$
\begin{aligned}
& \mathrm{FS}=2.8 \times 0.96=2.688 \\
& \mathrm{FA}=1.2 \times 0.96=1.152 \\
& \mathrm{FA}=0.65 \times 0.96=0.624
\end{aligned}
$$

To calculate the $\mathrm{CaO} \%$ used, from both carbonate and clay, to combine with $\mathrm{SiO}_{2}, \mathrm{Al}_{2} \mathrm{O}_{3}$ and $\mathrm{Fe}_{2} \mathrm{O}_{3}$; follow these steps: -

\section{For carbonate analyzed samples}

Multiply the modified factors by $\mathrm{SiO}_{2}, \mathrm{Al}_{2} \mathrm{O}_{3}$ and $\mathrm{Fe}_{2} \mathrm{O}_{3}$ relative percent recorded for carbonate analyzed sample (Table 3). 
Geochemical and geotechnical studies on carbonates

$\mathrm{SiO}_{2} \%$ used in cement $=2.668$ (modified factor) $\times 1.52\left(\mathrm{SiO}_{2} \%\right)=$ $\mathrm{Al}_{2} \mathrm{O}_{3} \%$ used in cement $=1.152$ (modified factor) $\times 0.26\left(\mathrm{Al}_{2} \mathrm{O}_{3} \%\right)=$ $\mathrm{Fe}_{2} \mathrm{O}_{3} \%$ used in cement $=0.624$ (modified factor) $\times 0.25\left(\mathrm{Fe}_{2} \mathrm{O}_{3} \%\right)=$ So, the total $\mathrm{CaO} \%$ used from carbonate sample in cement $=$

The $\mathrm{CaO}$ remained $=43.3(\mathrm{CaO}$ in carbonate $)-4.51=38.8$

For clay analyzed samples :-(G.Gendali Area, after Ibrahim, et.al 2015)

$\mathrm{SiO}_{2} \%$ used in cement $=2.668$ (modified factor $) \times 45.60\left(\mathrm{SiO}_{2} \%\right)=$ $\mathrm{Al}_{2} \mathrm{O}_{3} \%$ used in cement $=1.152$ (modified factor) $\times 12.02\left(\mathrm{Al}_{2} \mathrm{O}_{3} \%\right)=$ $\mathrm{Fe}_{2} \mathrm{O}_{3} \%$ used in cement $=0.624$ (modified factor) $\times 6.65\left(\mathrm{Fe}_{2} \mathrm{O}_{3} \%\right)=$ So, the total $\mathrm{CaO} \%$ used from clay sample in cement = The $\mathrm{CaO}$ required $=139.66-13.76(\mathrm{CaO}$ in clay $)=125.90$

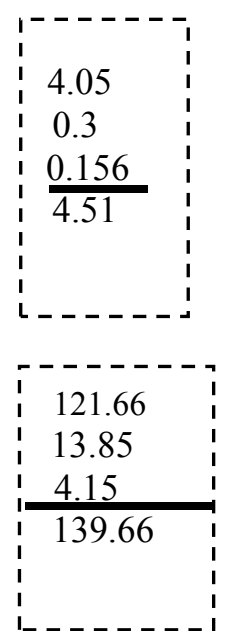

The Calculated ratio between the $\mathrm{CaO}$ required for clay and the remained $\mathrm{CaO}$ in carbonate.

$$
\begin{array}{rr}
\text { Ratio }=125.90 / 38.8 & =3.24 \\
\text { Ratio }=3.24: 1 & =0.764: 0.236
\end{array}
$$

To determine the required amounts of chemical oxides from both carbonate and clay (Table 6), aiming to calculate Silica modulus (S.M), Alumina ratio (A.R) and Lime saturation formula (L.S.F).

\section{For carbonate}

Multiply the factor $0.77 \mathrm{xSiO}_{2} \%, \mathrm{Al}_{2} \mathrm{O}_{3} \%, \mathrm{CaO} \%, \mathrm{MgO} \%$ and $\mathrm{SO}_{3} \%$.

\section{For clay}

Multiply the factor $0.23 \times \mathrm{SiO}_{2} \%, \mathrm{Al}_{2} \mathrm{O}_{3} \%, \mathrm{CaO} \%, \mathrm{MgO} \%$ and $\mathrm{SO} \%$. The computed values are shown in (Tables 5,6,7,8 and 9).

Table 5: Average chemical composition major oxides (in wt.\%) of the studied mud rock sections (G.

\begin{tabular}{|c|c|c|c|c|c|c|}
\hline Age & Rock Type & $\begin{array}{l}\text { Major } \\
\text { Oxides }\end{array}$ & SEC.A & SEC.B & SEC.C & Average \\
\hline \multirow{6}{*}{ 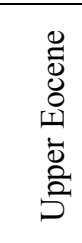 } & \multirow{6}{*}{\begin{tabular}{l}
$n$ \\
0 \\
0 \\
0 \\
\multirow{0}{0}{} \\
$\sum$
\end{tabular}} & $\mathrm{SiO}_{2} \%$ & 43.49 & 48.59 & 44.74 & 45.61 \\
\hline & & $\mathrm{Al}_{2} \mathrm{O}_{3} \%$ & 13.02 & 11.31 & 11.74 & 12.02 \\
\hline & & $\mathrm{Fe}_{2} \mathrm{O}_{3} \%$ & 6.66 & 6.22 & 7.09 & 6.66 \\
\hline & & $\mathrm{CaO} \%$ & 14.43 & 13.30 & 13.54 & 13.76 \\
\hline & & $\mathrm{MgO} \%$ & 3.22 & 3.19 & 4.17 & 7.80 \\
\hline & & $\mathrm{SO}_{3} \%$ & 1,71 & 0.36 & 0.94 & 1.00 \\
\hline
\end{tabular}
Gendali Area, after Ibrahim et al., 2015).

Table 6: Average chemical composition major oxides (in wt.\%) for the studied carbonate rocks sections (G. Galala area).

\begin{tabular}{|c|c|c|c|c|c|c|c|c|}
\hline \multicolumn{2}{|c|}{$A G E$} & FORMATIONS & $\mathrm{SiO}_{2}$ & $\mathrm{Al}_{2} \mathrm{O}_{3}$ & $\mathrm{Fe}_{2} \mathrm{O}_{3}$ & $\mathrm{CaO}$ & $\mathrm{MgO}$ & $\mathrm{SO}_{3}$ \\
\hline \multirow{2}{*}{$\begin{array}{c}\text { Lower } \\
\text { Eocene }\end{array}$} & \multirow{2}{*}{ Ypresian } & Minia Fm. & 0.71 & 0.04 & 0.052 & 34 & 14.75 & 0.25 \\
\cline { 3 - 9 } & Galala Fm. & 1.52 & 0.26 & 0.25 & 43.3 & 6.5 & 0.13 \\
\hline
\end{tabular}

Table 7: Required amounts of chemical composition major oxides (in wt.\%) from both carbonate and clays (Galala Fm.).

\begin{tabular}{|c|c|c|c|c|c|c|c|}
\hline Age & Rock type & $\mathbf{S i O}_{2}$ & $\mathbf{A l}_{2} \mathbf{O}_{3}$ & $\mathbf{F e}_{2} \mathbf{O}_{3}$ & $\mathbf{C a O}$ & $\mathbf{M g O}$ & $\mathbf{S O}_{3}$ \\
\hline \multirow{2}{*}{$\begin{array}{c}\text { Lower } \\
\text { Eocene }\end{array}$} & Mudrocks & 10.5 & 2.8 & 1.5 & 3.2 & 1.8 & 0.23 \\
\cline { 2 - 8 } & Carbonates & 1.2 & 0.2 & 0.2 & 33.3 & 5 & 0.1 \\
\hline \multicolumn{2}{|c|}{ Sum } & 11.7 & 3 & 1.7 & 36.5 & 6.8 & 0.33 \\
\hline
\end{tabular}


Kamel, et al.

Table 8: Required amounts of chemical composition major oxides in (wt.\%) from both Carbonate and clays (Minia Fm.).

\begin{tabular}{|c|c|c|c|c|c|c|c|}
\hline Age & Rock type & $\mathbf{S i O}_{2}$ & $\mathbf{A l}_{2} \mathbf{O}_{3}$ & $\mathbf{F e}_{2} \mathbf{O}_{3}$ & $\mathbf{C a O}$ & $\mathbf{M g O}$ & $\mathbf{S O}_{3}$ \\
\hline \multirow{2}{*}{$\begin{array}{c}\text { Lower } \\
\text { Eocene }\end{array}$} & Mudrocks & 9.1 & 2.4 & 1.3 & 2.7 & 1.56 & 0.2 \\
\cline { 2 - 8 } & Carbonates & 0.57 & 0.03 & 0.04 & 27.2 & 11.8 & 0.2 \\
\hline \multicolumn{2}{|c|}{ Sum } & 9.67 & 2.43 & 1.34 & 29.9 & 13.4 & 0.4 \\
\hline
\end{tabular}

Silica modulus (S.M) factor, Alumina ratio (A.R) and Lime saturation formula (L.S.F) for the studied carbonate sections (Galala area) was computed to test their validity for cement industry (Table 9)

A - Silica modulus (S.M) $=\frac{\mathrm{SiO2}}{\mathrm{Al203+ \textrm {Fe } 2 0 3}}$

Silica modulus (S.M) factor in Portland cement (Table 10) reveals that the studied carbonate Sections (Galala area Area). Southern Galala FM and Minia FM. Are suitable for high silica cement industry

$\mathrm{B}$-Alumina ratio $($ A.R $)=\frac{A l 203}{F e 203}$

The higher the $\mathrm{A} / \mathrm{F}$ ratio the greater is the proportion of $\mathrm{Al}_{2} \mathrm{O}_{3}$ relative to $\mathrm{Fe}_{2} \mathrm{O}_{3}$. The viscosity of the flux is affected by the composition; the higher ratio gives more viscosity. Alumina ratio (A.R) factor reveals that the studied carbonate Sections (G. Galala area) have moderate viscosity.

C-Lime saturation formula $(\mathrm{L} . \mathrm{S} . \mathrm{F})=\frac{\mathrm{CaO}-0.7(\mathrm{SO})}{2.8 \mathrm{SiO2}+1.2 \mathrm{Al2O}+0.65 \mathrm{Fe} 2 \mathrm{O} 3}$

Lime saturation formula (L.S. F) factor in Portland cement must do not exceed than 1.02 and not less than 0.66. From the previous studies, it clear that the studied carbonate Sections (G. Galala area) raw materials are very suitable for cement industry.

Table 9: -Validity of the studied carbonate sections (Galala area) for cement industry.

\begin{tabular}{|c|c|c|c|c|c|}
\hline \multicolumn{2}{|c|}{ AGE } & FORMATION & (S.M) & (A.R) & (L.S.F) \\
\hline \multirow{2}{*}{ Lower Eocene } & \multirow{2}{*}{ Ypresian } & Minia Fm. & 2.5 & 1.76 & 0.97 \\
\cline { 3 - 6 } & & Galala Fm. & 2.54 & 1.84 & 0.85 \\
\hline
\end{tabular}

\section{CONCLUSIONS}

The studied area is subdivided into two Formations in the G. Galala area from base to top: Galala Fm. and Minia Fm. Aggregates influence, to a great extent, the load transfer capability of pavements. Hence it is essential that they should be thoroughly tested before using for construction. Not only that aggregates should be strong and durable, they should also possess proper shape and size to make the pavement act monolithically. Aggregates are tested for strength, toughness, hardness, shape, and water absorption. The result of carbonate physical tests, for the studied carbonate sections shows their validity for road bases construction.

Silica modulus (S.M) factor in Portland cement reveals that the studied carbonate sections (Galala area). Southern Galala and Minia Fms. are suitable for high silica cement industry. The higher the A/F ratio the greater is the proportion of $\mathrm{Al}_{2} \mathrm{O}_{3}$ relative to $\mathrm{Fe}_{2} \mathrm{O}_{3}$. The viscosity of the flux is affected by the composition; the higher ratio gives more viscosity. Alumina ratio (A.R) factor reveals that the studied carbonate Sections (G. Galala area) have moderate viscosity. Lime saturation formula (L.S. F) factor in Portland cement must do not exceed than 1.02 and not less than 0.66. It clear that the studied carbonate sections (G. Galala area) raw materials are very suitable for cement industry.

\section{REFRENCES}

AASHTO T 104 99 $9^{\text {th }}$ Ed., (1999): Standard Method of Test for Soundness of Aggregate by Use of Sodium Sulfate or Magnesium Sulfate, published by American Association of State Highway and Transportation Officials (AASHTO), P.11. 
Geochemical and geotechnical studies on carbonates

AASHTO T 112 (2000): Standard Method of Test for Clay Lumps and Friable Particles in Aggregate, published by AASHTO, P.5.

AASHTO T 182-84 (2002): Standard Method of Test for Coating and Stripping of Bitumen-Aggregate Mixtures Published by American Association of State and Highway Transportation Officials, P.6.

AASHTO T 19-80 and T 20-42 (2013): Standard specification transportation materials and methods of sampling and testing Thirty-Third Edition published by American Association of State Highway and Transportation Officials (AASHTO), P.12.

AASHTO T 255-76 (2020): Sample Sizes for Moisture Content of Aggregate, published by AASHTO, P.5.

AASHTO T 290 (1995): Standard Method of Test for Determining Water-Soluble Sulfate Ion Content in Soil, published by AASHTO, P.10.

AASHTO T 291(1994): Standard Method of Test for Determining Water-Soluble Chloride Ion Content in Soil, published by AASHTO, P.11.

AASHTO T 85: (2018): Standard method of test for specific gravity and absorption of coarse aggregate published by American Association of State Highway and Transportation Officials (AASHTO), P.10.

AASHTO T 96 (2020): Standard Method of Test for Resistance to Degradation of Small-Size Coarse Aggregate by Abrasion and Impact in the Los Angeles Machine, Published by AASHTO, P. 6.

Armstrong, T. (2013): An Overview of Global Cement Sector Trends, Technical Congress FICEMAPCAC, Lima, geotechnical studies. 19(2), 121-138.

ASTM International - ASTM D4791-05 (2005): Standard Test Method for Flat Particles, Elongated Particles, or Flat and Elongated Particles in Coarse Aggregate, published by ASTM International, P. 4.

Blezard, R. G. (2004): The History of Calcareous Cements. In Hewlett, Peter C., ed. Lea's chemistry of cement and concrete. $4^{\text {th }}$ ed. Amsterdam: Elsevier Butterworth-Heinemann, 6(2), 1-24.

Boukhary M, Hussein AI, El-Morcey IA (2002): Lower Eocene larger foraminifera from Helwan, Greater Cairo, Egypt. Rev Micropaleontology (Paris), 45(1), 27-47.

BS 812-110: (1990): Testing aggregates. Methods for determination of aggregate crushing value (ACV) Published by BS, P.8.

BS 812-112: (1990): Testing aggregates. Method for determination of aggregate impact value (AIV) Published by BS, P.10.

Dylan and Moore (2014): Cement Kilns: Clinker Thermochemistry. Cement kilns. co. uk. Archived from the original. 3(1), 52-68.

Flugel, E., (2004): Microfacies of carbonate rocks: analysis, interpretation and application. Springer, New York, 976p.

Ibrahim A. M., Sakr S., and Abdel Aziz A. M (2015): Geochemical studies on some raw materials and their suitability for cement industry, North Eastern Desert, Al-Azhar Bull. Sci., 26, 123-141.

Issawi B, Francis M, Youssef A, Osman R (2010): The Phanerozoic of Egypt: a geodynamic approach. Ann., Geol. Surv. Egypt, Spec. Publ., 27(2), 589p

Loukina S. M., Abou El-Anwar E. A. (2018): Geochemistry of Lower Eocene carbonate rocks, Egypt. Geol. Surv Egypt 38(1), 141-156.

McArthur, Hugh, and Duncan Spalding (2014): Engineering materials science: properties, uses, degradation and remediation. Chichester, U.K.: Horwood, 23(3), 200-217.

Salman, D. M. (2017): An Assessment to the Oligopoly Cement Industry in Egypt: Is It A Curse or A Blessing?' Int. J. Green Economics, 11(1), 41-61.

Selim S. S. (2011): Paleoenvironmental modeling and paleogeography for the Upper Senonian-Paleogene sequences, north of the Gulf of Suez, Egypt with especial emphasis on the red beds. Ph. D. Thesis, Cairo Univ., Giza, Egypt, 350p

Strougo, A., Bignot, G., and Abdallah A. M. (1992): Biostratigraphy and paleoenvironments of the Middle Eocene benthic foraminiferal assemblages of north central Eastern Desert, Egypt. M.E.R.C., Ain Shams Univ., Sci. Res 33(1), 131-150.

Tueckmantel C, Fisher Q. J., Knipe R. J., Lickorish H. and Khalil S. M. (2010): Fault seal prediction of seismic-scale normal faults in porous sandstone: a case study from the eastern Gulf of Suez rift. Egypt Mar. Petrol Geol., 27(2), 334-351. 
Kamel, et al.

دراسات جيوتقنية و جيوكيميائية لصخور الكريونات بطريق القطامية -عين السخنة ومدى ملائمتها فى قواعد للطرق وصناعات الأسمنت

$$
\begin{aligned}
& \text { شريف كامل'، عاطف ابراهيم' و أحمد لطفى' } \\
& \text { جامعة الأزهر ، كلية العلوم، قسم الجيولوجيا، القاهرة، مصر }
\end{aligned}
$$

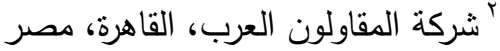

$$
\begin{aligned}
& \text { الخلاصة }
\end{aligned}
$$

يتتاول البحث دراسات جيوكيميائية وجيونقنية لصخور كربونات الإيوسين السفلى (Lower Eocene) (طريق القطامية -

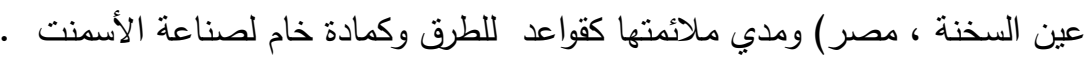
أوضحت الدراسات الليثوستراتجرافية إمكانية تقسيم الصخور الكربونية لعصر الإيوسين السفلى الى وحدتين صخرينين من أسفل إلى أعلى هما متكون الجلالة ومتكون المنبا.

من خلال الدراسة الجيوكيمبائية والجيوتقنية أمكن استتناج أن صخور الكربونات فى هذه المنطقة ملائمة كقواعد للطرق وكمادة خام لصناعة الأسمنت . 